\title{
The Persecution of Pilot Mackey
}

\section{Janet Maybee}

Francis Mackey était le pilote de port affecté au Mont Blanc, vapeur français chargé d'explosifs qui ont détoné à Halifax en décembre 1917 à la suite d'une collision avec le navire norvégien l'Imo. La participation de Mackey dans le désastre et l'enquête qui a suivi sont brièvement décrites dans cet essai qui se concentre, cependant, sur un aspect jusqu'ici obscur de l'histoire de Mackey: sa lutte pendant quatre ans, après le relâchement d'accusations criminelles contre lui, pour faire revalider sa licence qu'il avait volontairement mise en suspens, et le refus inflexible de C.C. Ballantyne, ministre de marine, de le réintégrer dans son emploi professionnel. Il semblerait que les autorités fédérales ont trouvé en Mackey la facilité de détourner la colère publique qui aurait peut-être pu exposer leurs défaillances en matière de contrôle de trafic portuaire menant au désastre.

"He has been openly and with dramatic intensity, and premeditated insult, accused of perjury...The bones of the departed have been drawn before him, and the tolling of the funeral bells have been brought to his attention, and he has been charged in the most direct, emphatic and insulting fashion of abusing his conscience and his oath..."

Humphrey Mellish

For nearly a century, Halifax harbour pilot Francis Mackey has borne blame for the catastrophic explosion of 6 December 1917. Mackey chanced to be the local pilot assigned to Mont Blanc, the heavily-laden French munitions ship that blew up after a collision with the Norwegian Imo. The blast inflicted destruction of unprecedented scope on the Nova Scotian capital: two thousand dead, more than six thousand injured, at least ten thousand homeless, thirty-five million dollars' damage to property and harbour facilities, and a five-day interruption in the convoying of men and materiel to the European War. Accused of manslaughter, jailed, deprived of his pilot's licence and branded as villain in the Halifax Herald's provocative headlines, Francis Mackey was pilloried in the aftermath of the explosion. Even the notice of his death, four decades

1 Summation by Humphrey Mellish, KC, 31 January 1918, Wreck Commissioner's Inquiry, Library and Archives Canada (LAC) Record Group (RG) 42 Vol. 596/7, 1983. Mellish, the mild-mannered lawyer (soon to become judge) representing the owners of Mont Blanc, finally protested the combative interrogation style of Charles Burchell, $\mathrm{KC}$, lawyer for Imo.

The Northern Mariner/le marin du nord, XX No. 2, (April 2010), 149-173 


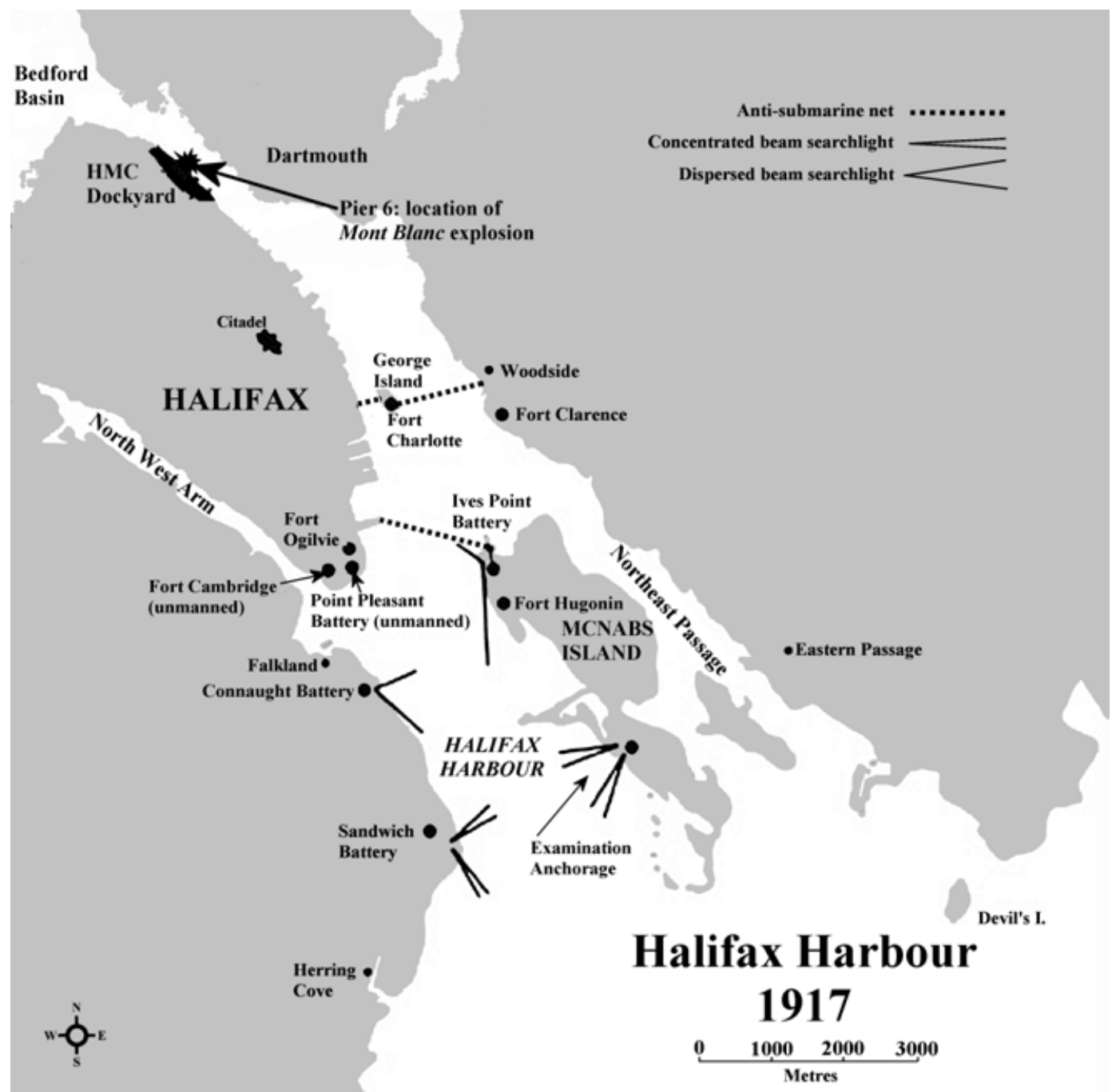

Illustration 1: Halifax harbour, 1917. Sources: from Canadian Military History vol.18 no 2 (Spring 2009), 58; with additional detail from J. G. Armstrong,Halifax Explosion, 13.

later, contained an editorial reminder of Mackey's connection with the disaster. ${ }^{2}$

Why was it that the press, local officials and federal authorities were determined to focus on Pilot Mackey as scapegoat, even though two others, Mont Blanc's captain Aimé LeMédec and the Royal Canadian Navy's Chief Examining Officer Frederick

2 Chronicle Herald, 1 January 1962. "Captain Francis Mackey, pilot of one of the two vessels involved in the 1917 Halifax explosion, died Sunday at his home in Spryfield. He was 89. Captain Mackey was pilot in charge of the French steamer Mont Blanc, which was in collision Dec. 6 with the Norwegian steamer Imo in the Halifax Narrows. The Mont Blanc carried about 1000 tons of TNT. The resulting explosion killed at least 1600 , injured 6000 and left 10,000 homeless." 
Wyatt, were also charged at the same time with manslaughter and criminal negligence? Why did it take more than four years of frustrated efforts and finally legal action for Mackey to repossess his pilot's licence? And why, even then, was his seemingly legitimate appeal for financial restitution rejected? The discovery of previously unexplored pilotage service files at Library and Archives Canada (LAC) and audio tapes at Nova Scotia Archives and Records Management (NSARM), as well as letters in the private collection of Mackey's descendants has provided new resources for studying the plight of an individual caught in a web of bizarre circumstance and official obfuscation.

\section{The Event}

The tragedy began to unfold on 5 December 1917 as Mont Blanc, loaded in New York with a deadly cargo of picric acid, gun cotton, TNT and benzol, arrived at the harbour entrance to join a slow convoy to France. The submarine nets guarding Halifax against German U-boats were already in place for the night; Mont Blanc had to anchor and wait for daylight. Francis Mackey, a respected harbour pilot of twenty-four years' experience, had already come aboard and accepted Captain Aimé LeMédec's invitation to stay until morning, despite learning the volatile nature of the cargo: no striking of matches was allowed on that deck. Mackey asked the Canadian navy's examining officer for special orders to ensure safe passage of this floating bomb; none were received. ${ }^{3}$

Meanwhile, during the afternoon of 5 December, the Norwegian steamer Imo, in ballast and in haste to reach New York to load relief supplies for Belgium, had been prevented from leaving Bedford Basin, the inner most part of Halifax harbour, because coal delivery for her fuel bunkers came too late. Her pilot, William Hayes, who was Mackey's longtime friend and colleague, went home for the night, leaving word for the chief examining officer, Acting Commander Frederick E. Wyatt, RCN, that Imo had not sailed, but apparently the message did not reach Wyatt. ${ }^{4}$

At first light on 6 December Mont Blanc received the signal from the navy examination service to proceed through the harbour and into Bedford Basin; the overloaded vessel crept slowly along the Dartmouth shore. At the same time Imo, travelling at a speed that appeared to some observers in excess of the harbour limit of five knots, ${ }^{5}$ turned into the Narrows - the constricted passage that links Bedford Basin with

3 Francis Mackey, Canadian Broadcasting Corporation recorded interview, Nova Scotia Archives and Records Management, AR 1267-1269, 1958.

4 Ibid. Mackey believed that Wyatt had been out all evening at a wedding and did not check on Imo the next morning.

$5 \quad$ Halifax Herald, 17 December 1917: "The Imo, when first sighted, was carrying white foam at her bow and was exceeding the speed limit set by the Admiralty." Evening Mail, 22 December 1917: Mate Walter Brannen of the tug Stella Maris testified at the Inquiry that the Imo was on the Dartmouth side "going as fast as any ship he had ever seen in the harbour" with foam at the bow. The Privy Council judgement summarizes in considerable detail Mackey's testimony at the Wreck Commission Inquiry and does not challenge his assertion that "the Imo's speed appeared to him to be above the speed fixed by the Admiralty regulations"; see Privy Council Appeals Nos. 129 and 130 of 1919, Judgement of the Lords of the Judicial Committee of the Privy Council (hereinafter referred to as Privy Council 
the main harbour - and initially was forced away from the Halifax side towards the Dartmouth side, in Mont Blanc's path, by the presence of other vessels. Mackey signalled Mont Blanc's desire to claim her proper channel, but Imo's whistles indicated apparent intent to keep heading toward the same water. As a last desperate measure Mont Blanc, unable to go any closer to shore, swung out into the harbour, attempting to pass starboard to starboard; briefly it seemed the two ships were parallel and might pass safely. However, Imo almost at the same moment threw her engines into reverse, which caused her bow to swing to starboard and plow into Mont Blanc's hull, opening a huge gash. As Imo, now going astern, pulled away, friction created sparks which ignited the benzol pouring from ruptured barrels on the French vessel's deck.

Mont Blanc's crew, seeing it was impossible to fight the fire or open the seacocks, responded speedily to Captain LeMédec's orders: they lowered two lifeboats and rowed furiously for the Dartmouth shore, while the flaming vessel drifted toward Halifax and came to rest against Pier 6. Twenty minutes after the collision, intense heat caused a massive blast, hurling shattered fragments of metal skyward to descend on the city in deadly black rain. ${ }^{6}$ A vast area of the city, the community once known as Richmond, was destroyed by the concussion and the fires that followed. Windows in all parts of the city were shattered with enormous force, causing terrible injuries to those inside the buildings. Imo's Captain From and Pilot Hayes were killed.

Francis Mackey, blown into the tangled limbs of an uprooted tree on the Dartmouth shore, regained consciousness alongside the French captain. While the foreign crewmen were assembled and taken aboard the British cruiser HMS Highflyer, Mackey made his way alone through the shambles of Dartmouth to the ferry, reported to the pilotage office, and walked through the city's chaos to Robie Street in search of his family. He found them shivering on the Commons, fearing a second explosion, the oldest daughter bleeding from glass fragments in her face. Mackey installed storm windows over the gaping frames of his damaged house, swept up the glass shards and made a pot of tea around midnight. ${ }^{7}$

With the inspiration of local resources and eyewitness accounts, many writers and dramatists have ably documented details of the events leading up to the explosion, the immense damage caused and the valiant rescue and restoration efforts which followed; there is no need to retrace their journeys. ${ }^{8}$ However, to this date none have

Judgement), 22 March 1920, LAC, RG 12, vol. 2827, 6.

6 For detailed analysis of the explosion and its consequences, see David Simpson and Alan Ruffman, "Explosions, Bombs and Bumps: Scientific Aspects of the Explosion, Ground Zero (Halifax 1994), 275-364.

7 Mackey, CBC interview 1958. Perhaps the pilot, like so many other survivors that day, was in shock, a state of numbness where even the most grievously affected seemed to feel no pain; wounded medical and military people simply kept on helping to rescue and treat others. "People worked strenuously and almost without sleep. The power of endurance ... was almost beyond belief. The anaesthetic effect of shock may have been a factor in this." Anonymous, "Psychology of the Explosion," NSARM, NG 36C, 8.

8 The online bibliography (http://www.halifaxexplosion.org/biblio/biblio1.html) contains most 
pursued the Mackey story or documented the harassment he faced for years after the disaster. The city's newspapers, publishing again within hours, reveal the distress and then anger of the people still alive, fearful and anxious to find someone to blame for this horror, once the early rumours of German attack proved unfounded. ${ }^{9}$ Francis Mackey's name was often in the headlines in the ensuing days and weeks, and the suspicion that fell upon him lingered long after he was cleared of criminal charges.

\section{Inquiry and Legal Battles}

Federal authorities moved quickly to set up a Wreck Commission Inquiry, presided over by Justice Arthur Drysdale, a judge of the Admiralty Court, assisted by the redoubtable and much-feared Dominion Wreck Commissioner Louis A. Demers ${ }^{10}$ and Captain Walter Hose of the Royal Canadian Navy. The proceedings began on 13 December, adjourned a week later, and resumed for ten days at the end of January. Such

of the numerous works and references. Of particular help in this project has been the dedicated research over three decades of Janet Kitz, whose interviews with survivors and study of relief commission documents and mortuary bags revealed and preserved stories which would otherwise have been lost.

9 Halifax Herald, 10 December 1917: "The investigation into the cause of this horrible disaster should not begin or end with an examination of the crews of the steamers concerned. If men higher up or lower down, through incompetency or duplicity, are to blame, let it be known ... we owe this much to the dead, the suffering wounded and to the friends who are left to sorrow." Daily Echo, 11 December 1917: "The people are vitally interested in bringing out the whole truth about the cause of a catastrophe which in its burden of tragedy and sorrow has probably never been parallelled in history."

10 Demers was a prominent and forceful commissioner in many high-profile formal investigations, including the 1909 accident in the St. Lawrence River when Empress of Ireland struck an uncharted wreck or rock; he did not accept excuses or extenuating circumstances. There are several examples recorded of his unforgiving approach to mariners deemed to have erred. "The collision was investigated by the Dominion Wreck Commissioner, Capt. L. A. Demers, who was noted for his highly critical assessments and severe judgments. Capt. B. W. Bongard of the TURBINIA had his license suspended for one year as he was found 'in default for not ordering any reduction in speed when he found his one-whistle passing signal went unanswered by PRIMROSE.' Capt. Alex Brown of PRIMROSE drew Capt. Demers' caustic ruling that he was 'incompetent as a master because he seemed to have his entire thought centred on making the dock and maintaining his schedule.' His master's license was permanently revoked." The Scanner, Toronto Marine Historical Society, V, 6 (March 1973). The case of Lambton, wrecked on Lake Superior in a severe winter storm that sank at least four other vessels, provided more evidence of Demers' merciless style: "She took a tremendous beating from the heavy seas once she stranded and soon was enveloped in a virtual mountain of ice. Before her crew could be rescued some days later, two men had died. An investigation of the accident was conducted by the muchfeared Capt. L. A. Demers, Dominion Wreck Commissioner. The LAMBTON's skipper, Capt. Livingstone, and the other officers were exonerated from blame in the deaths of the two crewmen but, as might be expected, the Commissioner found fault with someone for the stranding and this time it fell to the mate, C. E. Poster, to receive a reprimand from Demers." The Scanner, VI, 7 (April 1974). 
accident investigations were intended to determine the sequence of events and to gather evidence on navigation decisions, particularly any deviations from accepted rules of the road. In this unique situation, perhaps because the owners of both ships had so much at stake, the hearing became a battle about blame more than a search for truth. Citing what was described as the unethical behaviour of belligerent lawyers and an obviously biased judge, one legal historian characterized the process as "another calamity." 11 The commission had no authority to conduct a trial, and yet the atmosphere became stormy with accusations and insinuations which the rabid press published as fact. The inquiry's purpose was derailed by politically-charged controversies, and the subsequent Privy Council judgment noted that "much, if indeed not the greater part, of the evidence is irrelevant" to the issues which should have been its focus. ${ }^{12}$

Francis Mackey came willingly to testify but spent three days (15 - 17 December), far more than any other witness, on the stand being grilled, contradicted, threatened, falsely accused of drunkenness and lying, and generally bullied by Charles J. Burchell, KC, lawyer for the owners of Imo. "Repeatedly he browbeat and misled witnesses, disregarded all the rules of courtroom etiquette, and, on a number of occasions, violated the standards of legal ethics to which lawyers must subscribe ... Burchell and the judge orchestrated the Inquiry to the point where it became more of a kangaroo court than a dispassionate examination of the facts." ${ }^{13}$ Throughout the ordeal, Mackey remained calm and unshakable in denying Burchell's charges and describing the events of 6 December clearly. ${ }^{14}$ His testimony generally supported that of Captain LeMédec, and impressed Crown Counsel William Henry with its consistency, but was dismissed as utterly unreliable by Drysdale and Demers.

A brief and blunt decision (4 February 1918) followed the inquiry with astonishing speed and an even more startling lack of detailed analysis: disregarding the plentiful evidence that did not support his opinion, but heavily influenced by Demers' harsh assessment, Judge Drysdale placed total responsibility for the collision on Mont Blanc, its captain Aimé LeMédec, and particularly the pilot, Francis Mackey. He recommended that Mackey's licence be cancelled and that criminal prosecution should

11 Donald Kerr, "Another Calamity," Ground Zero, 365-374. For the full record of the wreck commissioner's inquiry and subsequent appeals, see LAC, RG 42, 596/7.

12 Judgment of the Lords of the Judicial Committee of the Privy Council, 22 March 1920, LAC, 9704-244, pt. 3, RG 12, 2827, 3. (Hereinafter Privy Council Judgment).

13 Kerr, 369.

14 The Privy Council Judgment gives a critical summary of the evidence produced by the inquiry, and notes that the statements given by Mackey, and the captain and crew of Mont Blanc were consistent, and that "of the independent witnesses examined, several ... corroborate, in substance, the officers and crew of this ship." Privy Council Judgment, 9. For a more detailed account see John Griffith Armstrong, The Halifax Explosion and the Royal Canadian Navy (Vancouver, 2002), 123-185. Crown Counsel W. A. Henry had also declared confidence in the pilot's testimony: Henry to Johnston, 22 December 1917, LAC, 9704-244, pt.1, RG 12, 2827. 
follow because of his "gross negligence and violation of the rules of navigation."15 Drysdale was equally severe in his assessment of Frederick Wyatt, declaring him guilty of neglect of his duties as the port's Chief Examining Officer; although the recommendation of the inquiry was merely "discipline" for Wyatt, he was promptly arrested and charged with manslaughter along with LeMédec and Mackey. ${ }^{16}$ Drysdale readily accepted Demers' only uncritical pronouncement: "Pilot Hayes and the crew of the Imo are exonerated. As he was a victim of the disaster, and has lost his life, and therefore cannot defend himself I cannot and will not even blame him for not reporting his departure from Bedford Basin to the Naval Authorities." 17

Crown Counsel William Henry, a respected Halifax lawyer who had tried throughout the inquiry process and in his reasoned summation to bring balance to the otherwise emotionally charged proceedings, reported his surprise at the outcome to Alex Johnston, the deputy minister of marine (who had commissioned Henry to organize the inquiry, secure the essential witnesses and represent the federal government). Henry noted that among seasoned mariners and informed legal sources there had been a strong expectation Imo would have been condemned for being on the wrong side of the channel, rather than having all fault assigned to Mont Blanc. He predicted, correctly, that higher courts would not come to this same conclusion. ${ }^{18}$

It fell to Nova Scotia's crown prosecutor to decide whether to act upon Judge Drysdale's recommendations, and again there was no lengthy deliberation. On 5 February 1918, the day after Drysdale's report appeared, a preliminary hearing on charges of manslaughter against Mackey, Wyatt and LeMédec began before Magistrate Robert MacLeod. Crown prosecutor Andrew Cluney added a charge of criminal negligence; hearings continued sporadically through the rest of that month. On 6 March 1918 all three defendants were committed to stand trial in the death of William Hayes. ${ }^{19}$

Wyatt and LeMédec were able to post bail but Mackey was imprisoned. However, by this time he had acquired a capable lawyer: Walter O'Hearn quickly brought forward a habeas corpus application, which requires the crown to demonstrate there is sufficient evidence to proceed against the accused. In response, Judge Benjamin Russell released Mackey from custody and from prosecution on 15 March 1918. LeMédec was also set free, but when Wyatt made his court appearance on 19 March he was committed to stand trial, despite Russell's instructions. In less than a day (16 April 1918) Russell convinced the jury there was no case against Wyatt and the crown did not appeal. Wyatt

15 Report of Justice L. J. A.Drysdale, 4 February 1918, LAC, NSS 80-5-13, RG24, vol. 5671.

16 Halifax Herald, 5 February 1918.

17 Demers to Drysdale, Borden Papers, LAC, MG 26H, vol. 90, reel C-4325, 46876, 28 January 1918.

18 William Henry to Alex Johnston, LAC, 9704-244, pt. 2, RG 12, vol. 2827, 4 February 1918.

19 Halifax Herald, 17 December 1917, bore the headline "Did Another Hand than Pilot's Direct Imo's Course?" Mackey's testimony expressed his puzzlement over the strange signals coming from the Imo, not at all what he expected to hear from a fellow pilot whose communications he had always understood. According to family members, to the end of his life Mackey maintained the belief that Hayes was not in control of the Imo that morning. 
was swiftly demoted, dismissed from the navy and banished; last reported in Boston, he disappeared from public records. ${ }^{20}$

There was absolutely no evidence, in Judge Russell's view, to support charges of either manslaughter or criminal negligence against Pilot Mackey. "It seemed to me," Russell reflected in his autobiography, "that so far from being negligent or careless, as charged in the information, [Mackey] had taken every possible care to prevent the collision which was about to be caused by the conduct of the Imo." Judge Russell was castigated in the press and on the streets for this unpopular decision; in his memoirs he noted that some irate citizens suggested he ought to be castrated. ${ }^{21}$

The explosion's terrible devastation had left the people of Halifax in a state of high anxiety and anger, desperate to assure themselves that the villain responsible was no longer a threat to their safety; in their eyes Francis Mackey had condemned himself above all by having survived, and by supposedly failing to warn others of the danger. ${ }^{22}$ Indignant provincial and city officials, including Chief of Police Hanrahan and Mayor A. C Hawkins, made several subsequent attempts to have the pilot hauled into court again (the final effort as late as March of 1919); these charges were dismissed on the basis of Judge Russell's decision. ${ }^{23}$

Before conclusion of the criminal proceedings, the owners of the two vessels involved undertook to sue each other for damages of two million dollars. Judge Drysdale presided over the first civil liability case in Admiralty Court on 1 April 1918, even though adherence to principles of justice would have demanded he recuse himself. From the opening moments he made it clear his decision was already firm: Mont Blanc and Pilot Mackey were absolutely at fault. He discredited the testimony of the one new witness (John Makiney, who was adamant that Imo was in the wrong, and had had a clear view of the two ships on the fateful morning that enabled him to give accurate evidence), accused Halifax lawyer Hector McInnes, now representing Mont Blanc after Humphrey Mellish became a judge, of coaching the witness to bear false testimony, and further berated

20 John Griffith Armstrong, The Halifax Explosion and the Royal Canadian Navy (Vancouver 2002), 205. Armstrong suggests Wyatt's punishment was due to his criticism of superior officers more than to any actual wrongdoing; the navy could not tolerate disloyalty.

21 Benjamin Russell, Autobiography (Halifax 1932), 271.

22 Mackey and Captain Aimé LeMédec, knowing only too well the extreme danger the ship's cargo posed, urged the crew to the lifeboats as there was no hope of extinguishing the fire or sinking the Mont Blanc. They reached the Dartmouth shore just before the blast and one French sailor was killed. Angry accusations were loud in the press and at the inquiry: they had shamefully sought to save their own lives and done nothing to warn others. There is considerable evidence they tried but were not heeded, as those on the water and on shore were distracted by the shocking sight of a ship afire. Furthermore, all Frenchmen were suspected of treachery at this point because of francophone Quebec's strong opposition to conscription.

23 See Alan Ruffman's overview of the lengthy criminal and civil processes, which appears as Note 12 following Donald Kerr's essay, "The Litigation," Ground Zero, 476-478. 
Judge Russell for setting Mackey free. ${ }^{24}$

Mont Blanc's owners, la Compagnie générale transatlantique, appealed Drysdale's decision to the Supreme Court of Canada, noting Imo's presence on the wrong side of the channel, her probable excessive speed and the series of incorrect signals. The Supreme Court recorded a split decision ${ }^{25}$ (19 May 1919) which in effect constituted a victory for Mont Blanc, and prompted the Southern Pacific Whaling Company, owners of Imo, to launch an appeal to the Privy Council in Britain, the highest court in the British Empire. Finally, in February 1920, the Judicial Committee of the Privy Council ruled that Mont Blanc had stayed in her own water, kept a moderate rate of speed and had little way on her when struck by Imo, which they concluded "must have struck that ship with more force and at a higher rate of speed than her witnesses admit." Their Lordships ultimately declared both ships at fault for not reversing earlier when apparently on a collision course, but felt the manoeuvre of Mont Blanc in the agony of collision, though it may not have been the best manoeuvre to adopt, was "in the circumstances excusable." 26 No individuals were personally sued and neither side gained any financial benefit, but Francis Mackey felt that he had been vindicated. None of these decisions provided legal grounds for compelling the minister of marine to reinstate the pilot but they probably had a positive effect on public opinion in Halifax.

Hector McInnes (who had acted for the owners of Mont Blanc but made it clear he did not represent Mackey) in a subsequent note to the deputy minister of marine pointed out that going astern was not an option for Pilot Mackey. The thrust of the ship's right-hand propellor would have thrown her bow right across the course of Imo. Further, by the time the collision appeared imminent, "she was so near the Dartmouth shore that the Mont Blanc was in danger of absolutely going ashore". ${ }^{27}$ Mackey had been warned that even a slight bump against a dock could spell disaster for his volatile cargo. Had the decision to go astern been taken much earlier that problem would not have arisen, but the captain and pilot of Mont Blanc had no reason to believe sooner that Imo would continue to steer into their channel.

Most researchers have assumed the Mackey file was closed upon his release by

24 Mate John Makiney, RNCVR, had an excellent vantage point at HMC Dockyard that made his testimony clear and credible in the opinion of William Henry and Judge Russell; Drysdale's closed-minded bias was obvious in his shocking charge that Makiney was lying. See John Griffith Armstrong, The Halifax Explosion and the Royal Canadian Navy (Vancouver 2002), 197. Unfortunately Drysdale's attack on Makiney's credibility led the Privy Council to put his report aside, despite acknowledging that he saw the collision and gave "most important evidence in favour of the Mont Blanc," Privy Council Judgment, 9.

"The Chief Justice and Mr. Justice Idlington were of opinion that the 'Mont Blanc' was alone to blame; Mr. Justice Brodeur and Mr. Justice Mignault were of opinion that the 'Imo' was alone to blame, and Mr. Justice Anglin that both ships were to blame. In this division of judicial opinion an order was made allowing the appeal, reversing the judgment of Mr. Justice Drysdale ...," ibid., 3.

26 Donald Kerr, "The Litigation," Ground Zero, 373-375.

27 Hector McInnes to Alex Johnston, 15 May 1920. Copy in Mackey family private files. 
Judge Russell. ${ }^{28}$ However, Francis Mackey's ordeal was far from over. The minister of marine, Charles C. Ballantyne, refused to restore the licence Mackey had voluntarily surrendered upon the laying of criminal charges against him. ${ }^{29}$ Despite his exoneration on those charges, Mackey was forced to spend the next four years and his life savings in a determined struggle to penetrate the wall of official secrecy surrounding the marine department's denial of his claim. Investigation of this previously uncharted part of Mackey's journey leads to some fairly clear evidence of political damage control operating in high gear.

The groundbreaking research of John Griffith Armstrong ${ }^{30}$ opened valuable records held only in Ottawa; he was the first historian to suggest Mackey had perhaps been unjustly treated. Following Armstrong's lead, this researcher located the revealing Mackey pilotage files held at Library and Archives Canada (LAC), containing documents unavailable at Nova Scotia Archives and Records Management (NSARM) and some redacted letters until very recently unavailable altogether. ${ }^{31}$ These files contain plentiful evidence of Ballantyne's inexplicable refusal to be swayed by Mackey's personal pleas, despite support Mackey received from harbour officials, the shipping community and the deputy minister of marine, the opinions of a respected judge in dismissing criminal charges, and even the strongly-worded advice of the minister of justice.

28 Michael Bird, The Town that Died (Halifax 1995), 182: "Mackey, who, following the report of the inquiry, had been suspended, was later reinstated as a pilot and completely vindicated." Janet Kitz, Shattered City (Halifax 1989), 171: "By this time [1920] Francis Mackey had been exonerated and reinstated as a pilot. He and his family had remained in Halifax, though at times their situation was difficult."Laura MacDonald, Curse of the Narrows (New York 2005), Appendix C: "Francis Mackey continued to work as a pilot in Halifax harbour for the rest of his life."Dean Jobb, Crime Wave (Halifax, 1991), 66: "Mackey, suspended in the wake of the commission's findings, was eventually reinstated as a pilot."

29 "Subsequent to my acquittal I applied to the said James Hall [formerly chairman of the Halifax Pilotage Commission but by then replaced as pilotage authority by Minister of Marine and Fisheries Ballantyne] for the return of my certificate and he then informed me that under orders of the Minister of Marine and Fisheries he was obliged to refuse the return of my certificate." Mackey's deposition to the Supreme Court of Nova Scotia, 19 August 1921, NSARM, MG 100, 183, 26.

30 Armstrong, 203. "What to make of this sorry mess of apparent intrigue and coverup? ... [the three scapegoats] had eluded formal punishment. They were nonetheless subjected to lasting resentment and contempt. None of them had been responsible for the circumstances that brought Mont Blanc to Halifax, however."

31 Access to some of the most revealing documents in this file was initially denied on the claim of solicitor-client privilege, and they were released only after sixteen months of appeals under the Access to Information Act through the Office of the Information Commissioner of Canada. The files are actually the property of Transport Canada; accordingly, LAC had to obtain their agreement for release. 


\section{Political Pressures}

Immediately after the explosion the newspapers and local politicians were vociferous in their demands for tightened regulations on the transport of explosives and assurance that such a tragedy could not be repeated,$^{32}$ but they were soon silenced by a subtle reminder from Ottawa that Halifax business interests would suffer unpleasant consequences from restricting wartime traffic. The minister of marine on 1 February 1918 responded to Mayor Peter F. Martin's appeals with this warning: "The view that no munitions ships should be laden or unladen at any pier in the Port would undoubtedly retard very seriously the prosecution of the war. You can best determine for yourself what influence it would have upon the future of the Port." ${ }^{\prime 33}$ It is within this context, where federal officials ranked national political concerns much higher than legitimate local or individual needs, that the Mackey saga takes on broader meaning.

What forces led to Judge Drysdale's swift delivery of such stern recommendations from the Wreck Commission Inquiry, the repeated attempts to prosecute the pilot, and the ongoing federal refusal to let Francis Mackey escape from his role as chief scapegoat? The list of possible factors might include the sensitive position of the prime minister, Sir Robert Borden, who was the member of Parliament for Halifax and who had arguably failed to protect his people from terrible harm. Should blame be laid at federal feet, there would be huge financial and political consequences. Certainly the outraged newspaper editorials were pointing in that direction: "The ultimate cause of all the trouble" opined the Quebec Telegraph, "was the lack of any system on the part of the authorities ... the captain and the pilot were simply instruments of an inexcusably weak and pernicious system ... The Government of Canada bears a colossal responsibility. The Minister of Marine is responsible for the negligence of his agents in this matter, and through him the whole Borden government must share the culpability." 34

As well, consideration might be given to the unusual situation of Charles $\mathrm{C}$. Ballantyne, a Montreal businessman who held no parliamentary seat when Borden appointed him minister of marine, the naval service, and also public works in October 1917. Ballantyne therefore was initially focussed on his urgent need to win the election which followed the explosion by less than two weeks (17 December 1917 but delayed in

32 The 1917 explosion was neither the first nor the last stemming from the presence of munitions in close proximity to the people of Halifax: in 1857 similar protests were raised after a munitions storage explosion and again in 1945 when fire threatened the Bedford Magazines. Citizens were largely unaware of the much more hazardous episodes of fire on munitions ships Trongate (9 April 1942) and Volunteer (November 1943), but "if Trongate had gone up, the resulting massacre would have made the original Halifax Explosion look like a Sunday School picnic." J. E. C. Porter, "The Night They Sank the Trongate," Atlantic Advocate, January 1963, 38. See also William Naftel, Halifax at War: Searchlights, Squadrons and Submarines 1939-1945 (Halifax 2008), 237-8. Volunteer was towed afire from Bedford Basin to McNabs Island and scuttled at Mauger Beach, a performance of astonishing risk and unsung heroism.

33 Ballantyne to Mayor P. F. Martin, LAC, RG 12, vol. 2822, 9704-244, pt.1, 1 February 1918.

34 “Government Responsible," Acadian Recorder, 14 February 1918. 
Halifax because of the disaster). Previously the owner of Sherwin Williams Paints in Montreal, president of the Canadian Manufacturer's Association and a member of the Montreal Harbour Board, the new minister's background in naval affairs was rather limited. ${ }^{35} \mathrm{He}$ would have been highly dependent on advice from his more experienced staff, particularly Georges Desbarats, deputy minister of the naval service, and Alexander Johnston, the deputy minister of of marine. Struggling to get a grip on his new responsibilities in the midst of crisis, Ballantyne faced a frustrating array of seemingly incompetent naval officers, ${ }^{36}$ headstrong pilots, panic-stricken citizens and sensational press coverage.

As the inquiry was unfolding, potential sources of embarrassment for the federal government had accumulated to a dangerous level. It became apparent that there was serious confusion as to who in fact controlled harbour traffic, with responsibility scattered among convoy officers of the British Navy, an RCN Captain Superintendent (Edward H. Martin, who was away in England on a top secret errand at the time ${ }^{37}$ ), Admiral Sir Charles Kingsmill, director of the naval service in Ottawa, various RCN dockyard officials including the hapless chief examining officer, Commander Wyatt, the civilian harbour master, Captain Francis G. Rudolf, whose authority in wartime when the navy assumed wider powers was unclear, and the pilots who had their own rather casual systems in place and had resisted attempts to exert control over their traditionally patronage-driven independent activities. ${ }^{38}$ Why had the federal government failed to establish a clear chain of command and to enforce strict regulations for handling the huge

35 Ballantyne's awareness of matters maritime came through a strongly business-oriented filter, and was dominated by his desire to build a Canadian Merchant Marine, chiefly to promote Montreal and its shipbuilding interests. See Kenneth S. MacKenzie, "C. C. Ballantyne and the Canadian Government Merchant Marine 1917-1921, Northern Mariner II, 1 (January 1992), 1-13.

36 For a detailed account of the turmoil in naval affairs during early 1917 in Halifax, see Michael Hadley and Roger Sarty, Tin Pots and Pirate Ships: Canadian Naval Forces and German Sea Raiders, 1880-1918 (Montreal 1991), 189-215. Mixed messages (or total lack of information) from the British Admiralty about Canada's wartime role, in addition to the pitiful state of RCN's fleet and raw recruits would have challenged even the most attentive Minister of Marine; unfortunately Ballantyne apparently "involved himself in the details of service affairs little more than Hazen had done." (215).

37 Hadley and Sarty, 209: Captain E. H. Martin had been sent to England in late November 1917 to determine what scale of attack Canada faced, what defences were needed, and what help might come from the Royal Navy after so many examples of bad advice, changes of plan and poor communication. The authors suggest there may have been another motive: his trip eased transition away from Halifax since he was to be replaced by Vice-Admiral W. O. Story, who would outrank the RN's convoy officer, Rear-Admiral B. M. Chambers, and perhaps be better positioned to solve the obvious harbour management problems.

Armstrong quotes Admiral Sir Charles Kingsmill: "“ The fact of the matter is that in and about Halifax, which is a hotbed of patronage, the Navy is not very popular, as from the first organization we have had to fight this very undesirable form of making appointments, that is patronage, and consequently gentlemen like the Mayor and the proprietor of the Halifax Herald do not love us."” Armstrong, 106. 
increase in shipping and hazardous cargo during the three years the war had been going on? Nervous Haligonians, whipped to a fury with each startling revelation swiftly noised abroad by the outraged press, wanted to know. ${ }^{39}$

Ballantyne made an emergency visit to Halifax a few days after Christmas, intent on reassuring the population that "no fault could be found with the work of port administration. Halifax was the best regulated port in any part of Canada." ${ }^{40}$ It is doubtful he convinced anyone. There was even more disturbing testimony to come when the inquiry reopened in late January. Shock waves rippled through Halifax and Ottawa when Commander Wyatt testified he had foreseen a potential catastrophe and had written Captain Superintendent Martin with his concerns ("I did not wish to be made the goat"), ${ }^{41}$ and that Martin had shown him federal documents indicating it would be unwise to punish the pilots for neglect of rules about reporting their movements to the chief examining officer.

Martin, somewhat vague and detached, and already replaced in the post of captain superintendent by Vice-Admiral W. O. Story, was unable to recall Wyatt's letters specifically. However, he testified he had on occasion raised his own concerns about management of the pilotage and had been told by Ottawa not to interfere with local conditions. ${ }^{42}$ Demers took particular umbrage at this news and wrote in a scathing memorandum to Judge Drysdale his opinion that "the controlling powers, upon receiving such a complaint, should have suggested a remedy, and ... recommended drastic measures to prevent such infringement of regulations. A tolerance of disobedience on the part of the pilots should never have been entertained." ${ }^{43}$

The threat of scandal was by this time palpable at the executive level. Prime Minister Borden's personal papers contain urgent requests to Ballantyne and his predecessor in the marine portfolio, J. D. Hazen, for clarification of Martin's remarks. Everyone denied knowledge of previous complaints, including Captain Martin himself, who couldn't imagine how Demers and the press could have so misinterpreted his testimony. ${ }^{44}$ Military historian J. G. Armstrong's research reveals that such documents had indeed reached the appropriate desks and no action followed. If this information had come to light before the inquiry ended, it would have confirmed "the already widely-held

39 W. C. Milner (journalist, railway promoter and dominion archivist for Nova Scotia and New Brunswick), personal letter to Prime Minister Borden: "The nervous tension here produced by the explosion has hardly yet subsided. People are discussing who has charge of the harbour. They have no confidence that another disaster will not occur. Admiral Chambers, Commander Wyatt and Captain Hose each disclaims being invested with any authority over harbour matters from Head Quarters.” LAC, Borden Papers, MG 26H, vol. 90, reel C 4325, 46752, 7 January 1918.

$40 \quad$ Halifax Morning Chronicle, 31 December 1917.

41 Wreck Commission Inquiry proceedings, LAC, RG 42, vol. 596/7, 703.

42 Ibid., 1610.

43 Demers to Drysdale, 28 January 1918, Borden Papers, LAC, MG 26H, vol.90, reel C-4325, 46878.

44 Martin to Borden, ibid., 46899-46918. 
belief that the Government of Canada, through its department of Naval Service, had been criminally negligent in contributing to the collision and, therefore, to the ensuing disaster." ${ }^{45}$

As soon as the Wreck Commission Inquiry concluded (30 January 1918), Ballantyne had quickly forwarded Demers' memos to the prime minister. ${ }^{46}$ These documents included strongly worded charges against Mackey and Wyatt. It would not be surprising in such circumstances, and with the growing public clamour for blame and punishment in editorials all across the land ${ }^{47}$ if Judge Drysdale might have been encouraged to waste no time on lengthy analysis but to accept Demers' harsh recommendations, which certainly seemed to coincide with the judge's own leanings, and issue an immediate, unequivocal condemnation of culprits other than federal ministers.

Wyatt, disgraced, quietly disappeared, while Aimé LeMédec went home to France and resumed his career. In 1931 he received the Legion of Honour for his thirtyfive years of service in the merchant marine. No doubt naval officials were optimistic that with Wyatt shuffled out of the spotlight the navy might escape further damage; unfortunately resentment against the navy lingered in Halifax for decades, despite the shifting of attention to the sins of the pilotage. Francis Mackey, the only Haligonian of the three defendants, thus remained as the lightning rod for citizen anger and government efforts to manage the situation. Speculative press reports from the inquiry had emphasized the scandalous amounts of money the pilots were rumoured to be making, perhaps illegally, ${ }^{48}$ and their complete disregard of naval authority over harbour traffic. The failure of federal officials to act upon proposals for improved control put forward at least a year earlier ${ }^{49}$ could well fade into the background if outrage focussed on Mackey. The Halifax Herald certainly kept his name prominent as guilty and unlikely to be proven innocent, and the numerous unfounded allegations hurled at him during the inquiry gave the public and politicians plenty of ammunition.

During the inquiry, lawyer Charles Burchell, acting with predictable vigour on behalf of Imo's owners, had certainly helped to draw the public's attention away from the politicians and bureaucrats with his berating of Mackey on the witness stand, accusing

45 Armstrong, 195

46 Demers to Drysdale, 28 January 1918, Borden Papers, LAC, MG 26H, vol.90, reel C-4325, 46874-8.

47 Truro Daily News, 7 December 1917: "The parties responsible ... should be hung in good oldfashioned style from the yardarm." Saint John Globe, 10 December 1917: "As the heartrending tragedy was directly the result of the war, the cost of making good the enormous personal and property loss should be assumed [by the federal government] not as a matter of benevolence but as a matter of duty." Ottawa Journal, 3 January 1918: "The port of Halifax is in charge of the naval authorities. What the public wants to know is - how does it come that a ship carrying 3000 tons of high explosives was permitted to wander about in the vicinity of a great residential district?"

48 Halifax Herald, 11 February 1918: “'Illegal Extortions of \$8000-a-year Pilots Exposed."

49 Armstrong, 119: "Proposals made in late 1916 by the Masters and Seamen branch of the Marine department to improve regulation of pilotage had not been acted upon." 
him of perjury, even mocking the pilot's inability to spell the French word for "halfspeed" as proof of his incompetence and guilt. ${ }^{50}$ William Dennis, owner of the Halifax Herald, assisted with an editorial (29 December 1917) listing, with unrealistic hindsight, all the actions Mackey should have taken to save the city, since he knew the terrible nature of the cargo. "The Pilot," Dennis concluded, "could have turned the ship into the Basin and allowed the crew to jump for their lives in the Narrows...There was time enough, and then he could have escaped himself. THAT would have been an act of heroism, and would have made Pilot Mackey glorious."

Despite these attacks, Francis Mackey proved unwilling to serve as a convenient diversion. Forty-five in December of 1917, with an impeccable record in the pilot service, Mackey possessed strength, resilience and more determination to survive than perhaps the Ottawa officials imagined. No doubt to their further surprise, he also maintained the respect and support of his fellow pilots and the shipping community. Nevertheless, Ballantyne dug in to his ill-advised position and resisted all efforts to reinstate the pilot for the next four years; only the minister's defeat in the 1921 election brought a change in Mackey's fortunes.

\section{The Pilotage Commission}

Even before the Wreck Commission Inquiry opened there had been concern that the Halifax Pilotage Commission was not accountable to anyone, and Deputy Minister of Marine Alex Johnston had expressed to Drysdale his view that for the duration of the war the minister should become the pilotage authority at Halifax. Crown Counsel William Henry argued that further examination of that problem area should indeed follow swiftly, but must not distract from the current inquiry. Johnston therefore immediately issued warnings to the Pilotage Commission that it was not to undertake its own investigation into the calamity.

Consequently the Pilotage Commission chairman, James Hall, had seen no reason why Francis Mackey should not continue to pilot ships in and out of the harbour as soon as the explosion debris was cleared away, especially since there were only fourteen pilots available to move the heavy wartime traffic. When this information surfaced during the inquiry there was uproar, fomented by Demers and feeding the Herald's frenzy. ${ }^{51}$ Frightening (and false) rumours were spread concerning a near collision involving one ship of the twenty or more Mackey had guided since the explosion; James Hall and Mackey himself had returned briefly to the stand to deny most categorically that any such dangerous incident had occurred ("I consider it the greatest piece of treachery that was ever perpetrated." ${ }^{, 52}$ )

The Royal Commission on Pilotage in Halifax, announced by Ballantyne even before the Wreck Commission Inquiry ended, and chaired by his friend Thomas Robb

$50 \quad$ Halifax Morning Chronicle, 19 December 1917.

51 The Halifax Herald, 29 January 1918, headlined in bold type: "Incomprehensible why Pilot Mackey should have been allowed to continue in his position."

52 Wreck Commission Inquiry proceedings, LAC, RG 42, vol. 596/7, 703. 


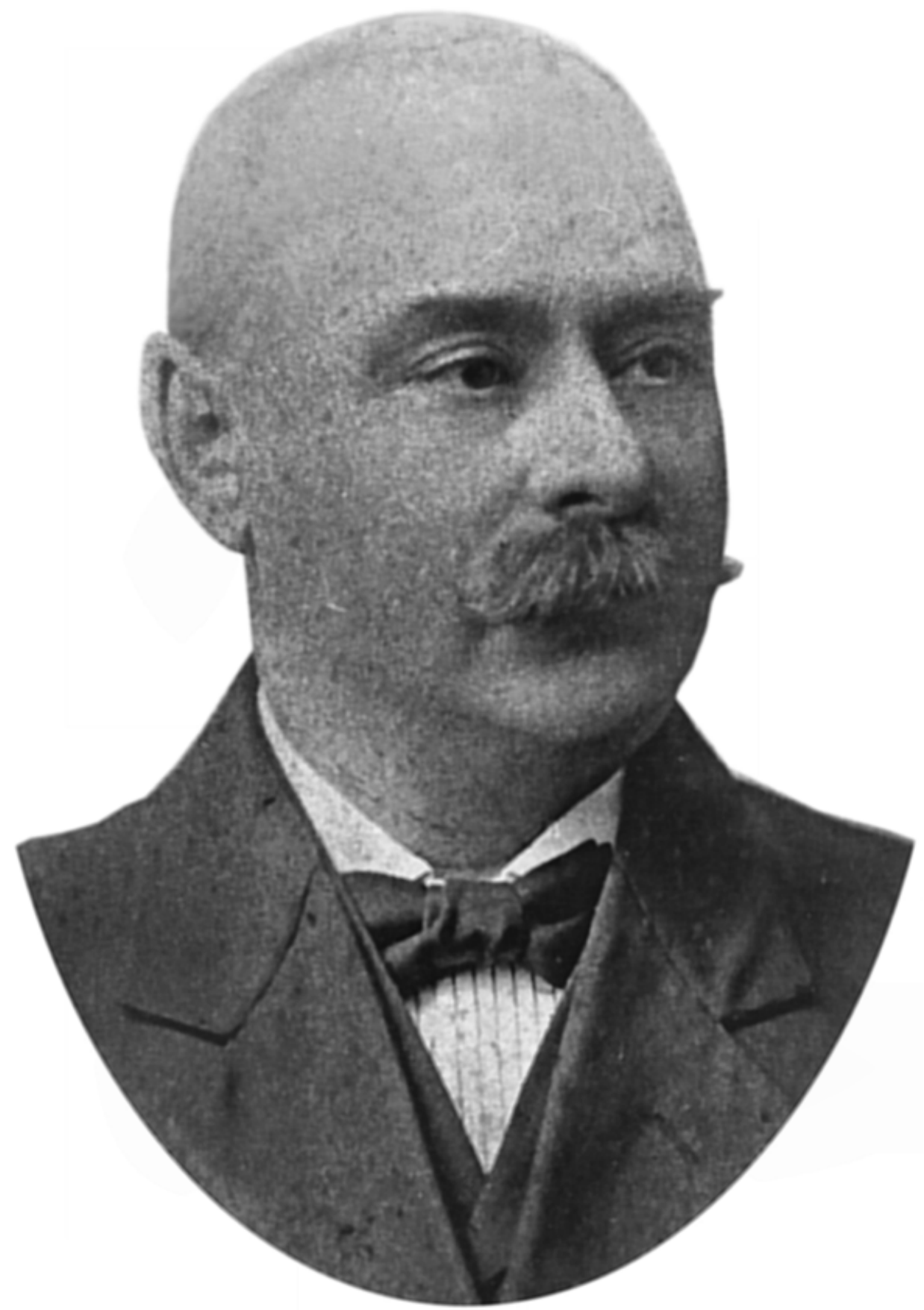

Illustration 2: Pilot of the Mont Blanc, Francis Mackey in mid life, possibly the early 1930s. Source: Joel Zemel, photograph digitally restored. 
from Montreal, began calling witnesses on 9 February 1918 while preliminary hearings on the manslaughter charges against Mackey, Wyatt and LeMedec were ongoing. Perhaps because of that much more dramatic competition, only one Halifax newspaper, the Acadian Recorder, reported in detail on the pilotage inquiry. ${ }^{53}$ Strangely, the explosion did not figure in the testimony. Chairman Robb made haste to deliver to Prime Minister Borden the expected recommendation, transferring control of pilotage in Halifax to the minister of marine, and by order in council on 14 March 1918 the Halifax Pilotage Commission ceased to exist. Four days later the Herald announced that LieutenantColonel H. St. George Lindsay "who for two years has been the most efficient embarkation officer at Halifax, has been appointed Superintendent of Pilots at Halifax." Lindsay had achieved some distinction as commissioner of the investigation into the collision between Empress of Britain and Helvetia in 1912, but he would presently find himself in trouble with the department of marine, caught up in the ongoing vendetta against Francis Mackey.

\section{The Quest for Reinstatement}

The day after Mackey's release by Judge Russell (16 March 1918), James Hall wrote urgently to Ballantyne asking that the minister, in view of Mackey's long and honourable record and the desperate need for qualified pilots, immediately restore him to active service. Apparently Alex Johnston, an extremely capable and experienced deputy minister, ${ }^{54}$ was left to handle the file as Ballantyne turned his attention to the much larger issue of managing a war effort that might soon end unpleasantly if shipping losses continued to increase. Johnston first sought advice from the dominion wreck commissioner, and got a sternly negative response from Louis Demers, who had not changed his assessment of Mackey's worth. Demers pointed out that with the Pilotage Commission now abolished, the minister should act at once to cancel Mackey's licence

53 There is no complete report of the Royal Commission on Pilotage in Halifax in either provincial or national archives, nor in the Library of Parliament. The commission report was tabled in the House of Commons by Ballantyne on 15 April 1918, but apparently was not printed. Since the outcome of the study was a foregone conclusion (it had already been assumed the War Measures Act would be employed to put the federal minister firmly in charge of pilotage in Halifax), perhaps debate was considered unnecessary. Decisions were needed before the imminent opening of Parliament might provide opportunity for embarrassing questions. Testimony during the pilotage hearings highlighted familiar communication problems: the pilotage commission and shipping interests had sent numerous recommendations to Ottawa concerning the need for more pilots and technical support but none had received answers.

54 Alexander Johnston, owner and editor of the Sydney Record, is credited with convincing Marconi to set up the first telegraphic facility in Cape Breton; he took a lifelong interest in the development of radio in Canada. An MLA in Nova Scotia, he resigned that seat to run for Parliament and defeated Sir Charles Tupper to become the Liberal MP for Cape Breton. After two terms he became deputy minister of marine and served in that capacity under ten ministers of various stripes from 1910 to 1933 . It is not surprising that Ballantyne trusted Johnston essentially to run the department while he pursued his shipbuilding crusade, and travelled to London and New York on war-strategizing errands. 
permanently "on the grounds of gross error of judgment." ${ }^{, 55}$ Johnston's telegram to Hall was terse: "Minister Marine and Fisheries will not approve reinstatement pilot Mackey." 56

Undeterred, Mackey engaged Walter O'Hearn, the lawyer who had successfully represented him before Judge Russell, to bargain with Ballantyne. O'Hearn tempered the request to the minister with an intriguing statement: "My client feels that his request at the present time to be restored to active duty as a pilot may, perhaps, embarass [sic] your department and he fully appreciates the delicacies and niceties of the situation; but he has instructed me to respectfully suggest that in view of the fact that a Pilotage steamer is being provided for this port, he might be given a position on board of her. ${ }^{, 57}$ An assistant deputy minster replied that the application would be considered. O'Hearn wrote to Mackey with this hopeful news, and even more welcome assurance that the attorney general for Nova Scotia had denied Mayor A. C. Hawkins' latest attempt to reintroduce criminal charges against the pilot. $^{58}$

Superintendent Lindsay apparently believed he had been given approval to install Mackey as master of the newly-acquired but decidedly unseaworthy pilotage steamer, Bayfield. ${ }^{59}$ Mackey had continued to petition the minister for the return of his licence and had even travelled to Ottawa for a fruitless meeting with Deputy Minster Alex Johnston. Mackey took command of Bayfield on 21 October. Within days there was a protest from Ottawa. B. F.Burnett, officer in charge of the Masters, Seamen and Pilotage branch, filed a complaint with Alex Johnston about Mackey's appointment, in Burnett's view made by Lindsay without ministerial authority. ${ }^{60}$ Burnett's memo reveals he harboured other grievances against Lindsay, and his information about Mackey's credentials was wrong. But Johnston, despite having given approval in his note on the original letter of request, ordered the immediate dismissal of Mackey. ${ }^{61}$

55 Demers to Johnston, LAC, RG 12, Vol. 1403, 8562-379 pt.1, 45813, 21 March 1918.

56 Johnston to Hall, ibid., 21 March 1918.

57 O'Hearn to Ballantyne, LAC, 8562-379 vol.1, 45813, 6 June 1918. Handwritten note on this letter: "approved, A. J."

58 O'Hearn to Mackey, 19 June 1918, private files of Mackey family. Hawkins was an outspoken, impetuous North End doctor and labour sympathizer, passionate about defending the people of his devastated part of the city. His term as mayor lasted only one year, much of it spent crusading to have Mackey brought back to court. See Henry Roper, "The Strange Political Career of A. C. Hawkins, Collections of Royal Nova Scotia Historical Society XLI (1982), 141.

59 Built in 1889 and originally named Lord Stanley, this boat had seen long service as a Great Lakes survey vessel until she was given to the Royal Canadian Navy in 1916 for coastal patrol duty. The navy's decision to hand her over for pilotage work would seem to indicate she was not ocean-worthy. After an extensive refit she went back to survey work in 1919, but was soon in need of repairs again and out of commission from 1922 until 1926. Ruth McKenzie, Admiral Bayfield - Pioneer Nautical Surveyor ([Ottawa]: Environment Canada, 1976). See also http://www.canfoh.org/Ships/Bayfield.htm.

60 Burnett to Johnston, LAC, RG 12, Vol. 1403, 8562-379 pt.1, 45813, 8 November 1918.

61 Johnston to Lindsay, ibid, 11 December 1918. 
Lindsay did not comply, and Mackey was still on the payroll in December, prompting the deputy minister to wire Thomas Robb with the minister's order to fire Mackey and suspend Lindsay as well. ${ }^{62}$ Despite Burnett's litany of complaints, Lindsay managed to save himself with a quick trip to Ottawa and a letter of apology. He was reinstated on 18 December, but the protest continued. Thomas Robb allied himself with Burnett and showed a degree of bias unpleasant in a royal commission chairman: "I think that the Minister's action in connection with Pilot Mackay [sic] being refused employment in the Pilotage Service...is one that ought to be highly commended by all right thinking people, and I am sure no one appreciates this more than myself." ${ }^{\circ 3}$

Mackey's brief employment on Bayfield was hardly a happy experience, ending not just because of Burnett's objections but because the vessel was unfit for service. In a Canadian Broadcasting Corporation interview taped in 1958, Mackey describes the desperate conditions on board: "Right in the middle of the fight [for restoration of his licence] they put on an old wreck of a steam pilot boat, the Bayfield, that was employed up in the lakes, and appointed me master. I knew it was trickery. Well, I took charge of her and she lasted about a month, and the last ship I took her out there for, I had to coax the engineers to plug the boilers up with rags and try to hold on. There was a southeaster springing up with snow specks, and of course it was a gale after. And the Olympic ${ }^{64}$ was due off Chebucto Head within an hour. Now there were the engineers singing out for me to 'Come in, come in,' the water was onto the fires. I said 'Is there any possible way you can keep this thing afloat until the Olympic gets here? I'd like to get a pilot aboard her. If she comes in here in thick snow it's not going to be good." "'65 Bayfield was consigned to refit and the pilot was again without employment.

In March 1919, while opposing lawyers Burchell and McInnes were contesting the appeal to the Supreme Court of Canada, Mackey was once more threatened with indictment but the Grand Jury in Halifax quashed this final attempt. On the strength of his apparent vindication by the highest court in Canada, Mackey's campaign to regain his pilot's licence became bolder. Through June and July a veritable cascade of supportive letters and endorsements landed on the minister's desk, including praise from the major shipping agents, T. A. S. DeWolf \& Son, Furness Withy, and Cunard Line. All expressed the view that popular sentiment had calmed in Halifax and there would be no outcry against Mackey's reinstatement. This reassurance ought to have eased any fears of political backlash.

J. Blanchard Henry, acting superintendent of pilots, declared that all the pilots

62 Johnston to Robb, ibid., 12 December 1918.

63 Robb to Burnett, ibid., 16 December 1918.

64 RMS Olympic was a sister ship of the ill-fated Titanic, and a crucially important troopship; by the end of the war she had carried 200,000 troops, and six months before this episode had rammed and sunk the German submarine $U-103$. Mackey had good reason to be concerned for her safety.

65 Francis Mackey, CBC recorded interview, NSARM AR 1267-1269, 1958. (This excerpt was not included in the six minute edited broadcast; the recording includes more than an hour of additional material including vivid details of his experience on 6 December.) 
were in favour of Mackey's return to active duty, and O'Hearn reminded Ballantyne that respect for "judicial opinion expressed by the members of the highest court in the land" would be proper and fitting. Lindsay, still onside despite the difficulty his support of Mackey had caused him, registered his belief that Mackey had been wrongly blamed, had suffered considerable loss, and deserved reinstatement, "he being a quiet, sober and respectable man." Even the superintendent of pilotage, G. E. L. Robertson, declared that "all interests are unanimous for the reinstatement of Pilot Mackey ... on account of his long years of service and heretofore having given every satisfaction." On Robertson's letter there appears a handwritten noted dated 7 October 1919 and signed by Deputy Minister Johnston: "Approved and recommended for favourable consideration of the Minister." ${ }^{\prime 66}$ Apparently Ballantyne ignored the advice even of his trusted deputy and made no written reply.

Upon learning that Robertson would be coming to Halifax, Mackey wrote a lengthy and impassioned appeal for a meeting with him, reviewing the history of his troubles and pointing out that he believed he had now been exonerated four times by the courts. "I have a wife and six young children to support, and find it very hard indeed, and have been subject to heavy legal expenses. I have spent the best of my life in the pilot service and consequently have not fitted myself for any other occupation, not having any opportunity to do so." ${ }^{\circ 7}$ Robertson must have been disappointed in his further attempts to sway Ballantyne, for his response on 9 October was brief: "I can only say that I have carefully gone into your case again, but I am unable to hold out to you any hope for your reinstatement." ${ }^{\prime 68}$

Through the winter Mackey, lacking good news from Ballantyne, found a few poorly paying jobs in Saint John NB and in Newfoundland. In March 1920, the National Association of Masters, Mates and Pilots of America intervened on Mackey's behalf with the minister of labour, who wrote to Ballantyne and got a response offering the minister of marine's excuse for continued refusal: "In view of the very serious consequences of the collision in which this pilot was involved, I have felt that I would not be warranted in restoring his license ... notwithstanding the decision of the Court to which allusion is made in your letter, I am fully persuaded that public opinion would be disturbed if pilot Mackey were again permitted to engage in piloting vessels in Halifax Harbour." ${ }^{69}$ Ballantyne advised that Francis Mackey should find some other employment.

The favourable Privy Council decision of 22 March 1920 gave Mackey reason to hope the minister's position might shift, though the ruling in a civil case provided no legal compulsion for Ballantyne to reverse his administrative decision. Mackey renewed his campaign, and in August of 1920 Hector McInnes, lawyer for Mont Blanc's owners, forwarded to Alex Johnston a petition for reinstatement signed by dozens of the

66 Blanchard Henry to Ballantyne, 6 June 1919; O’Hearn to Ballantyne, 14 June 1919; Lindsay to Ballantyne, 20 June 1919; Robertson to Ballantyne, 7 August 1919, LAC, RG 12, Vol. 1403, File 8562-379, 45813, pt.1.

67 Mackey to Robertson, ibid., 35-38.

68 Robertson to Mackey, ibid., 39.

69 Ballantyne to NAMMPA, ibid., 43-45. 
merchants and shipping interests of Halifax. The preamble pointed out that the Privy Council had affirmed the decision of the Supreme Court of Canada, "in which Sir Louis Davies, Chief Justice, exonerates Pilot Mackey from all blame. We feel that the litigation in connection with this unfortunate occurrence of December 6th, 1917, having been finally ended, that the facts have been fully ascertained, and we feel that it is only justice to Mr. Mackey to replace him in his former position.,70

Ballantyne was too busy to respond, perhaps in part because of the Halifax Shipyards strike in June and July (the minister, determined to establish a merchant marine fleet, had taken great interest in restoring this potentially lucrative operation and had involved several of his Montreal business colleagues in the project ${ }^{71}$ so Alex Johnston conveyed the official answer: "I discussed this matter very fully with him with the result that he considers it inadvisable to recede from the position he has already taken in this matter." In reply to a further appeal from Halifax Member of Parliament P. F. Martin, the minister's office issued on 24 September the identical letter sent to the minister of labour six months earlier. ${ }^{72}$

Mackey took the opportunity to meet with Ballantyne in person at the Halifax Hotel in December 1920 to discuss his situation, but by March of 1921 he was still waiting for the response the minister had promised to send the following week. His handwritten plea reveals considerable patience and forbearance in the midst of what must have been by then a crisis: "I have a wife and family of six children depending on me, and I am out of employment and the outlook is very dark indeed, and is looking worse from day to day ... I understand everything is in your hands re granting my renewal of license as pilot, and I hope you will consider it favourably. You will have the prayers of my family and myself at all times. Yours respectfully, Francis Mackey."73

\section{Mackey's Legal Challenge}

Ballantyne's response two weeks later was again a refusal, with no reason offered. At that point Mackey shifted from prayers to legal action. The next item in his file is a formal demand from lawyer L. A. Forsyth for the return of the pilot's certificate within ten days, as "the withholding of the certificate is illegal and unwarranted. We also

$70 \quad$ McInnes to Johnston, ibid., 47.

71 Suzanne Morton, "Labourism and Economic Action: The Halifax Shipyards Strike of 1920," Journal of Canadian Labour 22 (Fall 1988), 84: "During World War I, Canada realized a critical shortage of ocean tonnage and in 1918 the Department of Marine and Fisheries pledged that steel shipbuilding would be a peacetime priority. C. C. Ballantyne, Minister of Marine, sent Roy M. Wolvin, President of the Montreal Transportation Company, to Halifax where he agreed to enter the shipbuilding industry on condition of receiving the explosiondevastated and expropriated Graving Dock, sufficient space for a plant, and four government contracts for ships. In June 1918, Halifax Shipyards Limited, organized by Wolvin and J. W. Norcross, President of Canada Steamship Lines, took over the 46 acre site of the Halifax Graving Dock.”

72 Mackey Pilotage File, LAC, RG 12, Vol. 1403, File 8562-379, 45813, pt.1, 50.

73 Ibid., 51-52. 
understand that Pilot Mackie [sic] has used every amicable means to secure the return of his certificate." 74

The lawyer's letter was politely acknowledged but on the same day, 2 May 1921, E. Hawken, the assistant deputy minister of marine, forwarded several pages of the most damaging information he could find to the deputy minister of justice, seeking a legal opinion. The package included excerpts from the extremely negative Drysdale report and memoranda from Demers, but made no reference to the Supreme Court and Privy Council decisions favourable to Mackey. ${ }^{75}$

By 20 May 1921, Mackey's lawyer, having had no further news from Ottawa, observed that "the cancellation of this man's certificate is in direct violation of all the protective provisions of the Merchant's Shipping Act, and we feel we will have no difficulty in establishing that fact." 76 In view of Mackey's financial circumstances ("he is not overburdened with this world's goods"), lawyer Forsyth would not proceed recklessly with an action if there was a chance the minister might accede promptly. Johnston's response was to claim that the matter was now under review by the Department of Justice. Indeed it was, return correspondence from Justice on 26 May complained that there was a great deal of information missing from the marine department's initial submission, and noted that Judge Russell and the Supreme Court had exonerated Mackey. $^{77}$

Meanwhile, Pilot Superintendent Lindsay produced for Johnston what little material could be found in the previous Pilot Commission's minutes and letter books related to the Mackey case, and remarked that other documents were probably given to the royal commission's secretary in February 1918 and had not been returned. The evidence Lindsay provided confirmed Mackey's testimony that he had willingly handed in his licence to the commission, expecting its prompt return upon being cleared of manslaughter charges; that licence, Lindsay pointed out, was never cancelled and "is in this office." Furthermore, "Mackey being the only Halifax pilot holding a Master's Certificate (Coasting), and a superior in every respect to most of the pilots. it would be a pity to lose his services to this port." 78

The accumulating evidence of a miscarriage of justice was finally beginning to affect attitudes within the bureaucracy. Hawken, the marine assistant deputy who had previously tried to edit out all favourable evidence, had been forced to share Lindsay's comments with the justice department on 16 June 1921. He was, moreover,

$74 \quad$ Ibid., 54.

75 Ibid., 57.

76 Ibid., 59. Mackey's sworn deposition of 19 August 1921 claims "I am advised by my counsel and do verily believe that the cancellation of my certificate is illegal and unwarranted on the grounds that the provisions of the Merchants' Shipping Act, dealing with formal investigations of shipping casualties as affecting the certificates and licenses of Pilots, were not complied with." NSARM, MG100, 183, 26.

77 Ibid., 65-68; see note 26.

78 Ibid., 70-74. 
contemplating the possibility of restoring the licence and the possible consequences: "Should the Minister after having obtained the opinion of your department decide to reinstate Pilot Mackey, would Mr. Mackey have any claim for back pay, loss of time, or in any way have a claim. If so, against whom would the claim be." ${ }^{.79}$

It is evident from a letter sent to Deputy Minister Johnston on 23 August that there was awareness in the justice department of foot-dragging in the marine department. Some of the documentation requested three months earlier still had not been provided, and Deputy Minister of Justice E. L. Newcombe wrote with a tone of polite impatience: "May I remind you that in my letter of 26th May I put forward certain considerations favourable to the pilot which I think the Minister might reasonably take into account as justifying the restoration of Mr. Mackey's status and rights as a pilot, and I would suggest that the merits be considered again by the Minister in the light of the opinion expressed by Mr. Justice Russell and later by the Judicial Committee of the Privy Council, to which my letter of 26th May directed special attention." ${ }^{" 80}$

Lawyer Forsyth and his client had also lost patience. Notice was served to Ballantyne that a motion would be made on 21 October 1921 in the Supreme Court of Nova Scotia for an order for a writ of certiorari to remove into the Supreme Court the charge of the wreck commissioner in the Mont Blanc case. Hawken appealed to the deputy minister of justice to request that Ballantyne be represented by counsel. The reply from Justice on 27 September 1921 was pointed: contesting this case "merely on technical grounds would be unfortunate" and the smarter move would be for the minister to heed Newcombe's previous advice and restore the pilot's licence. ${ }^{81}$

Ballantyne apparently did not see the wisdom in this suggestion, and in early November both he and Demers were notified of forthcoming writs to appear at hearings of the Supreme Court of Nova Scotia; they could have attended by agreement but they both replied they would accept formal service of the writs. There appears a handwritten ministerial question on the lawyer's letter to Johnston: "What case is this, please?" and a response from Robertson: "re employment of Pilot Mackey." the Mackey file was still not the minister's top priority.

\section{Victory, in Part}

At this point the federal election of 6 December 1921 intervened. The resounding defeat of the Conservative government, and the new prime minster MacKenzie King's appointment of a powerful minister of marine, his Quebec lieutenant Ernest Lapointe, early in 1922, finally brought Mackey hope of a fair hearing. Forsyth wrote on 28 January 1922 to Alex Johnston, who remained as deputy minister of marine, that the matter of Mackey's licence must be taken up with the new minister at the earliest possible opportunity. The general superintendent of pilots, G. E. L. Robertson, followed

\begin{tabular}{ll}
\hline 79 & Ibid., 75 \\
80 & Ibid., 77. \\
81 & Ibid., 82. \\
82 & Ibid., 86.
\end{tabular}


on 6 February, quoting the justice department recommendation of the previous May, and asking that he "be authorized to issue a new licence to Mr. Mackey as a pilot for the District of Halifax." 83 Johnston's handwritten note in the margin on the same date says "Recommended Approved", and the next day he wrote Forsyth to announce Minister Ernest Lapointe's agreement. ${ }^{84}$

Francis Mackey noted on Pilot Superintendent Lindsay's letter inviting him to come in for vision testing, "Rec'd Licence on Feb 14th Valentines 1922." He refused to accept the new document sent from Ottawa and retrieved the original licence, identified by the small marginal cut he had made, from the bookshelf in the pilotage office where he had voluntarily secured it four long years previously. ${ }^{85}$

Mackey's impassioned and articulate letter of thanks to the Canadian Navigators Federation for its support provides rare insight into the personal trial he had endured. It was "a long fight against a band of piratical manipulators of justice, in order to vindicate myself, and compel them to return my license to me, and after four years (the mills of justice grinding exceedingly slow, but sure) it is now very gratifying to me to be able to tell you, my dear brothers, that I have beaten them all to the dust, and come through it all victorious, and with perfect eyesight and my license returned." 86

Triumph was temporary; the struggle was still not over. Lawyer Forsyth promptly wrote to the new and presumably more sympathetic minister of marine requesting compensation for four years of lost earnings: "It seems not unfair that $\mathrm{Mr}$. Mackey should receive a compassionate allowance from the Government for the fact that the erroneous and mistaken attitude of the Minister [Ballantyne] ... has put Mr. Mackey to great expense to re-establish himself in the Pilotage Service and to defend himself against charges which were found to be without foundation and has obliged him to practically consume the savings of his life's work to support his family during these barren years." ${ }^{\prime 7}$ It is not clear that Ernest Lapointe actually saw this request, but Alex Johnston dismissed it: "I am not sure that any useful purpose would be served by a further re-opening of the case. I think he should regard the action that has been taken as reasonably satisfactory." 88

Mackey and lawyer Forsyth did not agree, and launched an appeal in the Exchequer Court in August of 1923, declaring that Minister of Marine and Fisheries Ballantyne had "wrongfully and without legal justification or excuse" denied Mackey the right to make a living at his profession. ${ }^{89}$ Justice officials asked Alex Johnston for all the background files to enable the minister of justice to assess the claim, and these documents were supposedly delivered the next day, but mysteriously disappeared in a

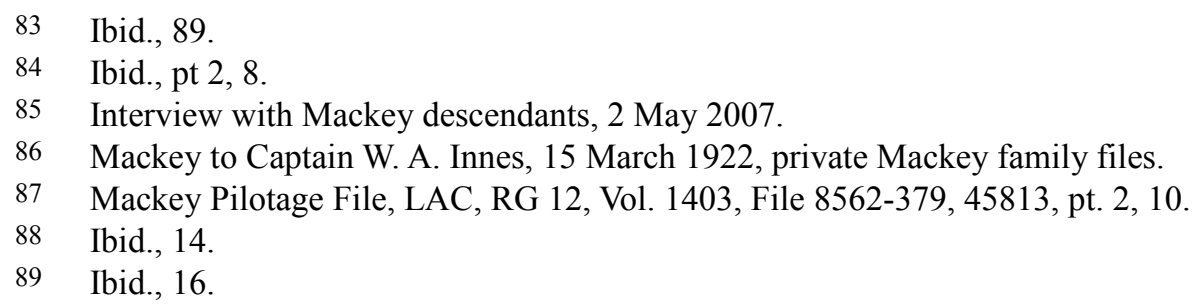


certain Mr. Varcoe's office. ${ }^{90}$ There is no further correspondence on the file save a note from the justice department returning the documents in April 1924. ${ }^{91}$ This sudden silence might indicate awareness on the part of the bureaucrats that their actions had not been praiseworthy, or that Mackey and his lawyer had decided not to proceed with the action.

No compensation was forthcoming, and probably Mackey gave up the fight in view of his beloved wife Lillian's serious illness and death in January of 1924, leaving him a widower with young children in his care. The cost of further legal services would have been overwhelming at that point, but Mackey's sense of honour made debt repayment a priority. His daughter Mona remembered walking once every week to lawyer Forsyth's office with an envelope of money; Mackey noted on one such envelope, "Last Payment \$12.69 April 1929."92

In the twenty-first century, since there has developed greater sensitivity and public awareness with regard to wrongful convictions, there would very likely be protests of unfair treatment and government would be pressured to make suitable restitution. The circumstances of Mackey's time of tribulation were very different: the horrific effects of war and explosion left thousands deprived of livelihood, homes and families. The devastated survivors had no part in the high level decision-making that involved them in a foreign war; they were no less the innocent victims, and often their pleas for help were rejected for reasons equally unacceptable to our modern sensibilities. It is possible that if Mackey had received compensation for his lost earnings, no matter how valid his claim, some antipathy toward him might have been rekindled among Halifax explosion victims also struggling to rebuild their lives with no direct help from their federal government.

Perhaps future study of Alex Johnston's papers will reveal that he foresaw such an outcome and by denying the appeal for compensation allowed Mackey to maintain his standing in the community as a respected pilot and fellow citizen sharing the challenge of recovery. Far more likely, federal officials wanted to avoid setting a dangerous precedent: repaying Francis Mackey would amount to admission of responsibility and might well open the floodgates to hundreds or thousands of claims. No wise deputy minister would welcome that blot on his copybook.

Francis Mackey went back to the dangerous challenge of piloting vessels in the harbour until he retired in 1937; C. C. Ballantyne became a senator. Pending further research, there is no clear evidence to explain Ballantyne's obstinate refusal to restore Mackey's licence. Was it simply arrogant reluctance to admit a mistake? Distraction as he dealt with the demands of war and the ambitious project to build merchant ships in Canada? Uncritical reliance on the opinions of Demers and Drysdale? Or did he fear that appearing to acknowledge the pilot's claim as justified would allow the spotlight to turn on the government's own failures and culpability in the Halifax tragedy? Whatever the reason, the consequences for Mackey and his family were lasting, severe and undeserved.

\footnotetext{
$90 \quad$ Ibid., 22.

91 Ibid., 23.

92 Mackey family files and interview with Mona Mackey Holmes, 22 January 2008.
} 


\section{AWARDS PRESENTED BY}

\section{THE NORTH AMERICAN SOCIETY FOR OCEANIC HISTORY}

\section{THE JOHN LYMAN BOOK AWARDS}

Each year NASOH presents the John Lyman Book Awards to recognize excellence in the publication of books which make significant contributions to the study and understanding of maritime and naval history. Books are honored in multiple categories of maritime and naval history. The award is named in honor of John Lyman (1921-1977), oceanographer, maritime historian, and a founder of NASOH.

\section{THE K. JACK BAUER AWARD}

In 1988, NASOH created the K. Jack Bauer Award to honor those who have given distinguished service to $\mathrm{NASOH}$ and who have made life-time contributions to the field of maritime history. The award is named in honor of E. Jack Bauer (1926-1987), naval historian and founder of the NASOH.

\section{CHAD SMITH STUDENT TRAVEL GRANTS}

NASOH provides funds to assist students in funding travel to its annual meeting to deliver a paper at the meeting. The award is named in honor of Philip Chadwick Foster Smith, maritime museum curator, maritime historian, and an early member of $\mathrm{NASOH}$.

\section{CLARK G. REYNOLDS BEST STUDENT PAPER AWARD} conference.

Each year NASOH honors the student who presents the best paper at its annual

$$
* \ldots *
$$

All award winners are normally announced at the banquet held in conjunction with NASOH's annual conference which is usually held in May. Inquiries concerning eligibility and application procedures can be directed to:

$\begin{array}{llll}\text { John Lyman } & \text { Dr. Gene Allen Smith } & \text { Other } & \text { James C. Bradford } \\ \text { Book Awards: } & \begin{array}{l}\text { Department of History } \\ \text { TCU Box 297260 }\end{array} & \text { Awards: } & \begin{array}{l}\text { Department of History } \\ \text { Texas A\&M University }\end{array} \\ & \text { 2800 University Drive } & & \text { College Station, TX 77843- } \\ & \text { Fort Worth, TX 76129 } & & 4236 \\ & \text { Telephone: 817/257-6295 } & \text { Telephone: } 979-845-7165 \text {, or } \\ & \text { E-mail: G.Smith@tcu.edu } & 979-775-5448 \\ & & \text { E-mail: jcbradford@tamu.edu }\end{array}$

